\title{
Natural Resistance of Seven Amazon Woods to Xylophagous Termite Nasutitermes octopilis (Banks)
}

\author{
Flávio Nascimento Costa ${ }^{1}$ (D), Rennan de Paula Cardoso ${ }^{1}$ (D), \\ Clebérton Santos Mendes ${ }^{1}$ (D), Pablo Ramon Garreto Rodrigues ${ }^{1}$ (D), \\ Alisson Rodrigo Souza Reis ${ }^{1}$ \\ ${ }^{1}$ Universidade Federal do Pará - UFPA, Altamira/PA, Brasil
}

\begin{abstract}
Some Amazonian woods are considered highly resistant to the attack of microorganisms; however, which ones present the highest resistance is unknown. This study aimed to evaluate the natural resistance of seven woods to xylophagous termite Nasutitermes octopilis through a no-choice feeding assay. The following wood species were assessed: Dinizia excelsa, Manilkara huberi, Dipteryx odorata, Bagassa guianensis, Astronium lecointei, Caryocar villosum, and Hymenolobium petraeum (Ducke). To this end, five timber samples from the middle heart at breast height of each plant with dimensions of $2.54 \times 2.54 \times 0.64 \mathrm{~cm}$ (longitudinal $\times$ radial $\times$ tangential) were collected from sawmills in the municipality of Altamira, Pará state, Brazil, submitted to termite action under laboratory conditions, and had their mass loss and wear assessed, with five replicates. A. lecointei showed the lowest resistance, whereas $C$. villosum and D. odorata presented the highest resistance.
\end{abstract}

Keywords: biodeterioration, xylophagous termites, no-choice feeding assay, Amazonian wood. 


\section{INTRODUCTION}

Timber is one of the main products of construction, and lumber is used in the manufacture of furniture, bridges, boats and crafts, as well as in civil construction (Rodrigues \& Brito, 2011). The native wood species from Amazon are the most sought and commercialized worldwide because of their quality and mechanical resistance, which ensure construction integrity and, consequently, the safety of individuals for a longer time (Stallbaun et al., 2017). However, because timber is a biological material, little is known about the biological resistance of Amazonian woods to different degrading organisms.

In Brazil, research on termite attack is scarce, and according to Gonçalves et al. (2013), most studies address dry wood termites. The genus Nasutitermes comprises most of the species of termites in the planet, and it is the most diverse and complex due to its adaptability to feeding and dwelling and its longevity compared with those of other insects of this order. Xylophagous termites are the best known as they are more commonly visualized and combated, mainly because they are considered pests by humans and present urban and rural distribution. Currently, there are approximately 2,882 species of termites cataloged worldwide, with 562 of them occurring in the Neotropical region (Constantino, 2015). Termites (Isoptera) can be classified according to their eating habit in xylophages, humivores, reapers, and intermediates (Ferreira et al., 2011).

Several researchers have conducted studies to assess wood resistance to termite attack using choice and no-choice feeding assays. Paes (2002) investigated the natural resistance of Corymbia maculata and only observed light wear, the author considered this wood as highly resistant; Paes \& Vital (2000) studied five species of Eucalyptus and found that termites degraded the less dense species; Silva et al. (2004) verified that Eucalyptus grandis presents low resistance regardless of the age of wood. However, Paes et al. (2007b) assessed seven native, exotic woods and observed no correlation between biological resistance and wood density.

Rodrigues \& Brito (2011) studied Pinus elliottii, Eucalyptus urophylla, and Corymbia citriodora and verified that Pinus timber presents higher resistance to Coptotermes gestroi; Gonçalves et al. (2013) investigated 10 Amazonian species and observed that the higher the density and the lower the extractive and ash contents, the higher the termite mortality; Stallbaun et al. (2017) evaluated the resistance of Sclerolobium paniculatum and classified its timber as highly resistant.

It is also worth noting the relevant contribution of the studies on the effects of natural extractives and thermal modification tests to assess wood resistance conducted by Paes et al. (2010, 2013, 2016), who evaluated the efficiency of Candeia (Eremanthus) tree oil, the effects of natural extractives, and heat treatment in various woods, and by Pereira et al. (2015), who tested the efficiency of burned oil against termite attack as a preservative in Amazonian woods.

Nevertheless, the contributions to Amazonian woods in these areas are still incipient, as in the cases of Angelim-vermelho, Angelim-pedra, Brazilian Teak, Bulletwood, Brazilian Tigerwood, Pequi, and Tatajuba, the main timbers marketed in the state of Pará, considering their good mechanical strength, high density, and use as structural parts in civil construction. In 2015 , a volume of $457,145,2673 \mathrm{~m}^{3}$ of these woods were legally marketed, with cubic meter value ranging from \$ 257.40 to \$ 716.10 (Pará, 2017).

In the Amazon region, the biological behavior of these termites is unknown. In addition, these woods are used without considering biological degradation - either by fungi or termites -, and this information is empirical and should be recognized by the science and technology of wood, thus generating technical-scientific information. In this context, the present study aimed to assess the natural resistance of the wood of seven forest species to the attack of xylophagous termite Nasutitermes octopilis under laboratory conditions through no-choice feeding assays.

\section{MATERIAL AND METHODS}

\subsection{Selection of woods and preparation of specimens}

The following wood species were selected: Angelim vermelho (Dinizia excelsa Ducke), Bulletwood (Manilkara huberi Ducke Stand), Brazilian Teak (Dipteryx odorata Aubl), Tatajuba (Bagassa guianensis Aubl), Pequi (Caryocar villosum Aubl.), Brazilian 
Tigerwood (Astronium lecointei Ducke), and Angelim pedra (Hymenolobium petraeum Ducke). The selection criterion was commercialization in the civil construction market for the purposes of permanent structures such as roofs and beams, in the municipality of Altamira, Pará state. Timber samples were collected at sawmills at the time of processing, with five samples per species and five replicates.

Test specimens with dimensions of $2.54 \times 2.54 \times 0.64 \mathrm{~cm}$ (longitudinal $\times$ radial $\times$ tangencial), composed only of heartwood, were prepared according to the American Society for Testing and Materials - ASTM D-3345 (ASTM, 2005b) norm. The specimens were oven dried $\left(103 \pm 2{ }^{\circ} \mathrm{C}\right)$ until constant mass was reached. After that, the mass of each sample was measured according to the ASTM D-1413 (ASTM, 2005a) norm and the values were used to calculate the mass loss of test specimens submitted to termite attack. In addition to the timber of native forest wood species, samples of Pinus sp. were used as standard comparison according to the ASTM D-3345 (ASTM, 2005b) norm. Basic density values were determined according to the ABNT NBR 7190/1997 norms, using a mean for each species (ABNT, 1997).

\subsection{Colony collection and capture of termites}

A termite colony was collected at a sawmill in the municipality of Altamira from ceiling beams located approximately $5 \mathrm{~m}$ above the ground. After collection, the colony was arranged in a water tank $(250 \mathrm{~L})$, which was supported on four bricks placed in plastic trays containing water to prevent the termites from escaping, according to the methodology described in Paes et al. (2013).

Termites were captured from the tank using square pieces of cardboard $(20 \times 20 \mathrm{~cm})$, moistened with distilled water to attract the insects and placed at the bottom of the tank, according to the recommendations by Paes et al. (2013). Collection of the termites occurred approximately $48 \mathrm{~h}$ after their migration from the colony to the cardboard pieces.

The cardboard pieces were disassembled on a tray and the termites transported to a 10-liter bucket containing 20 paper towels. Ten of these paper towels were moistened with distilled water, slightly kneaded, and placed at the bottom of the bucket, whereas the other 10 dry towels were used as a cover, as described in the ASTM D-3345 (2005b) norm. After $7 \mathrm{~h}$, the insects settled between the towels, with the weaker termites remaining on the dry towels and the more vigorous termites remaining on the moist towels. The dry paper towels were removed and discarded, whereas the moist ones were taken to the laboratory for collection of the termites.

\subsection{Preparation of the assay assembling flasks}

The no-choice feeding assay was assembled in $500 \mathrm{~mL}$ plastic flasks, washed and sterilized $(80 \%$ ethanol), to which $200 \mathrm{~g}$ of sterilized sand and distilled water were added to saturation point and kept at rest for $12 \mathrm{~h}$, according to the ASTM D-3345 (ASTM, 2005b) norm.

A specimen was then placed in each flask and buried in the sand up to half its length, embedded to the side so that it was visible for analysis from the outside of the flask. For each wood, five replicates were used in five randomized blocks ( 25 jars with sand and samples of timber and termites per species). The same procedure was adopted for the control.

$N$. octopolis termites $(1 \pm 0.05 \mathrm{~g})$ were weighed and added to the flask. Necessarily, $90 \%$ of the termites used were workers, because this class of individuals is responsible for the wood wear. After addition of the insects, the flasks were covered with thin cloth, as recommended by Paes et al. (2007a).

In addition, five flasks without wood samples (water, sand and termites only) were used to evaluate termite vitality. The flasks remained at temperature and relative humidity conditions of $27 \pm 2{ }^{\circ} \mathrm{C}$ and $75 \pm 5 \%$, respectively, for four weeks, as described in the ASTM D-3345 (ASTM, 2005b) norm.

\subsection{Statistical analysis}

Determinations of the ASTM D-3345 (ASTM, 2005b) norm were used as parameter to assess the mass loss and wear of wood (Table 1). The experiment was conducted in a randomized design, and the blocks represented the specimens of each forest wood species. The Lilliefors test was performed to verify the normality of data; as the data did not present normality, they were transformed into percentage and the Tukey's test was then applied for analysis of variances at $5 \%$ significance level $(p>0.05)$. 
Table 1. Evaluation of wood wear and termite mortality.

\begin{tabular}{|c|c|}
\hline Wood wear & Grade \\
\hline Sound, allowing superficial scarification & 10 \\
\hline Light attack & 9 \\
\hline Moderate attack, with penetration & 7 \\
\hline Heavy attack & 4 \\
\hline Failure, with rupture of the specimens & 0 \\
\hline Termite mortality & $(\%)$ \\
\hline Low & $0-33$ \\
\hline Moderate & $34-66$ \\
\hline High & $67-99$ \\
\hline Total & 100 \\
\hline
\end{tabular}

Source: Modified from ASTM D-3345 (ASTM, 2005b).

\section{RESULTS AND DISCUSSION}

Among the species evaluated regarding wood wear, Brazilian Tigerwood (Astronium lecointei Ducke) presented the lowest grade (7) (Table 2), characterized by moderate termite attack. The other assessed species presented light attack or remained sound. These results can be associated with the chemical composition of wood, because those that presented higher wear grades have higher natural extractive contents. As reported by several authors (Supriana, 1985; Rodrigues \& Brito, 2011; Paes et al., 2013), depending on the type and concentration of these compounds combined with high density, wood may present higher biological resistance.

Loureiro et al. $(1997,2000)$ classified Angelim-vermelho (Dinizia excelsa Ducke) wood as of high density $\left(0.83 \mathrm{gcm}^{-3}\right)$, a value lower than that found in this study $\left(1.05 \mathrm{gcm}^{-3}\right)$, and resistant to attack by xylophagous organisms; however, the authors did not identify such organisms. This wood species also presents low permeability, which assists with its natural resistance. Ferreira \& Hopkins (2004) associated density with thickness of the fiber wall, that is, the thicker the fiber wall, the denser the wood. Regarding the Angelim-pedra species, Paula \& Alves (1997) and Ferreira \& Hopkins (2004) reported that this wood presents density $>1 \mathrm{gcm}^{-3}$; however, Vasconcellos et al. (2001) mentioned a value of $0.72 \mathrm{gcm}^{-3}$, similar to that found in this study, showing the variation in wood density, which may influence biological resistance.

Gonçalves et al. (2013) classified the wood of Angelim-pedra as of moderate wear grade to the attack
Table 2. Mean values of wood wear and termite mortality according to species.

\begin{tabular}{lcc}
\multicolumn{1}{c}{ Species } & Wear grade & $\begin{array}{c}\text { Termite } \\
\text { mortality }\end{array}$ \\
\hline Pinus sp. (Control) & 7 & 100 \\
Dipteryx odorata & 10 & 100 \\
\hline Dinizia. excelsa & 10 & 100 \\
H. petraeum & 10 & 100 \\
A. lecointei & 7 & 50 \\
M. huberi & 9 & 100 \\
\hline B. guianensis & 9 & 100 \\
C. villosum & 10 & 100 \\
\hline
\end{tabular}

of Cryptotermes brevis; however, the present study demonstrated that this wood is resistant to the attack of $N$. octopilis, as it can be verified in Table 2. The high resistance can be explained by the chemical composition of this wood: $31.77 \%$ lignin, $11.52 \%$ extractives, $0.56 \%$ ash, $56.15 \%$ holocellulose, $47.36 \%$ cellulose, $5.90 \%$ xylose, $1.40 \%$ mannose, $1.02 \%$ glucuronic acid, and 0.40 galactose, according to Castro et al. (2015); these authors also found $1.08 \%$ tannins. Colodette et al. (2015) and Febrianto et al. (2015) reported that extractives can influence the physical properties, and that certain phenolic components can inhibit the attack of fungi and insects.

As for Bulletwood (Manilkara huberi Ducke Stand), density of $0.83 \mathrm{gcm}^{-3}$ was observed in the present study; however, Santos (1987), Paula \& Alves (1997), and Pereira (2013) found a density value $>1 \mathrm{~g} \mathrm{~cm}^{-3}$. Brazilian Teak (Dipteryx odorata Aubl) presented density of $1.07 \mathrm{gcm}^{-3}$, a result similar to those observed by Santos (1987) and Pereira (2013). Tatajuba (Bagassa guianensis) showed density of $0.79 \mathrm{gcm}^{-3}$, the same value obtained by Santos (1987) and Pereira (2013), who described this wood as resistant to termite attack.

At the end of the assays, it was possible to verify complete termite mortality in all tested wood species, except for Brazilian Tigerwood (Astronium lecointei Ducke) (Table 2), which presented moderate wear grade in relation to the attack of $N$. octoplis, according to the parameters shown in Table 1. Abreu \& Silva (2000) showed that high-density native species tend to contain more lignin and, consequently, more natural extractives such as quinones, terpenoids and polyphenols. These 
extractives, which act as natural defenses preventing the microorganisms present in the intestines of termites from fully digesting the cellulose, are the possible cause of the high mortality rate of insects, a fact also observed by Stallbaun et al. (2017).

Brazilian Tigerwood timber samples, as shown in Table 2, presented considerable susceptibility to termite attack compared with that of Pinus sp., which was used as control due to its low wear grade according to the ASTM D-3345 (ASTM, 2005b) norm. This finding can be explained by the quite selective feeding habits of these termites, which attack more avidly species they have more contact with, as reported by Stallbaun et al. (2017), suggesting that this situation occurred in the present study, because the colony obtained for the experiment came from a sawmill in a region where Brazilian Tigerwood timber is more abundantly stored and commercialized.

Another explanation may be the preference of termites for a particular wood. According to Lima \& Costa-Leonardo (2007), these insects present different feeding habits, and this difference can occur between and within (imagoes and soldiers) groups, in addition to be an important factor for the evolution of the species.

The mass loss observed in the experiment indicates that the woods assayed are naturally resistant to termites of the tested species, except for the Brazilian Tigerwood timber samples, which presented the highest percentage of mass loss (Table 3). According

Table 3. Mean values of basic density and mass loss according to species.

\begin{tabular}{|lcccc}
\multicolumn{1}{|c}{ Species } & $\begin{array}{c}\text { Basic } \\
\text { density } \\
\left.\text { (gcm }^{-3}\right)\end{array}$ & $\begin{array}{c}\text { Dry } \\
\text { mass } \\
(\mathbf{g})\end{array}$ & $\begin{array}{c}\text { Final } \\
\text { mass } \\
\mathbf{( g )}\end{array}$ & $\begin{array}{c}\text { Mean } \\
\text { values } \\
\text { of mass } \\
\text { loss (\%) }\end{array}$ \\
\hline $\begin{array}{l}\text { Pinus sp. } \\
\text { (Control) }\end{array}$ & 0.54 & 56.45 & 48.04 & $14.90 \mathrm{c}$ \\
\hline D. odorata & 1.11 & 114.88 & 112.95 & $1.67 \mathrm{a}$ \\
\hline D. excelsa & 0.60 & 62.42 & 60.86 & $2.5 \mathrm{a}$ \\
\hline H. petraeum & 0.65 & 67.57 & 62.71 & $7.19 \mathrm{~b}$ \\
\hline A. lecointei & 0.61 & 62.78 & 55.14 & $12.16 \mathrm{c}$ \\
\hline M. huberi & 0.58 & 59.85 & 55.75 & $6.85 \mathrm{~b}$ \\
\hline B. guianensis & 0.76 & 78.71 & 76.46 & $2.85 \mathrm{~b}$ \\
\hline C. villosum & 0.49 & 50.91 & 50.17 & $1.45 \mathrm{a}$ \\
\hline
\end{tabular}

Means followed by the same letter do not differ statistically by the Tukey's test $(p>0.05)$. to Stallbaun et al. (2017), high-density woods tend to decrease the fragmentation ability of termites, thus inhibiting their consumption. Nevertheless, it is consensus that, in order for natural resistance to be assessed, not only must the wood density and the amount of chemical extractives be evaluated, but also the chemical class of such extractives and their effects on different organisms (Paes et al., 2007a; Stangerlin et al., 2013; Marcondes et al., 2013). Alencar et al. (2011) did not find any correlation between mass loss and density for Sabiá (Mimosa caesalpiniifolia) wood, but found a difference between phenotypes (with or without aculei) and position of the wood in the pith-to-bark direction.

\section{CONCLUSION}

Dipteryx odorata (Brazilian Teak), Dinizia excelsa (Angelim-vermelho), Manilkara huberi (Bulletwood), Bagassaguianensis (Tatajuba), Caryocar villosum (Pequi), and Hymenolobium petraeum (Angelim-pedra) showed resistance to termite attack.

Pequi (Caryocar villosum) can be considered the most suitable wood for use in civil construction because it presents biological resistance (total termite mortality and absence of wood wear) and low mass loss after $N$. octopilis termite attack.

Brazilian Tigerwood (A. lecointei Ducke) presented the lowest wear grade and mortality rate and the highest mass loss.

Study of the chemical composition (cellulose, hemicellulose, predominant lignin type: syringyl or guaiacyl) and extractives of the wood of the species addressed in this study is recommended because of the termite mortality rate and the lifestyle of Nasutitermes octoplis termites.

\section{ACKNOWLEDGEMENTS}

The authors thank D.Sc. José Adriano Giorgi for the contributions and in the identification of the termite.

\section{SUBMISSION STATUS}

Received: 14 feb., 2017

Accepted: 30 june, 2018 


\section{CORRESPONDENCE TO}

\section{Flávio Nascimento Costa}

Universidade Federal do Pará - UFPA,

Rua Gurupá, 3309, CEP 68373-100, Altamira, PA,

Brasil

e-mail: flavio-nc9@hotmail.com

\section{REFERENCES}

Abreu RLS, Silva KES. Resistência natural de dez espécies madeireiras da Amazônia ao ataque de N. macrocephalus (Silvestri) e N. surinamensis (Holmgren) (Isoptera:Termitidae). Revista Árvore 2000; 24(2): 229-234.

Alencar FHH, Paes JB, Bakke OA, Silva GS. Resistência natural da madeira de sabiá (Mimosa caesalpiniifolia Benth.) a cupins subterrâneos. Revista Caatinga 2011; 24(1): 57-64.

American Society for Testing and Materials - ASTM. ASTM D-1413: standard test method for wood preservatives by laboratory soil-block cultures. West Conshohocken: ASTM; 2005a. 7 p.

American Society for Testing and Materials - ASTM. ASTM D-3345: standard test method for laboratory evaluation of wood and other cellulosic materials for resistance to termites. West Conshohocken: ASTM; 2005b. 3 p.

Associação Brasileira de Normas Técnicas - ABNT. NBR 7190: projetos de estruturas de madeira. Rio de Janeiro: ABNT; 1997. 107 p.

Castro JP, Perígolo DM, Bianchi ML, Mori FA, Fonseca AS, Alves ICN et al. Uso de espécies amazônicas para envelhecimento de bebidas destiladas: análises física e química da madeira. Cerne 2015; 21(2): 319-327. http:// dx.doi.org/10.1590/01047760201521021567.

Colodette JL, Gomide JL, Carvalho DM. Composição química de materiais lignnocelulósicos. In: Colodette $\mathrm{JL}$, Gomes FJB, editores. Branqueamento de polpa de celulósica: da produção da polpa marrom ao produto acabado. Viçosa: UFV; 2015. 816 p.

Constantino R. Cupins do Cerrado. 1. ed. Rio de Janeiro: Technical Books; 2015. 167 p.

Febrianto F, Pranata AZ, Septiana D, Arinana A, Gumilang A, Hidayat $\mathrm{W}$ et al. Termite resistance of the less known tropical woods species grown in West Java, Indonesia. Journal of the Korean Wood Science and Technology. 2015; 43(2): 248-257. http://dx.doi.org/10.5658/WOOD.2015.43.2.248.

Ferreira EVO, Martins V, Inda AV Jr, Giasson E, Nascimento PC. Ação das térmitas no solo. Ciência Rural 2011; 41(5): 804-811. http://dx.doi.org/10.1590/S010384782011005000044 .
Ferreira GC, Hopkins MJG. Manual de identificação botânica e anatômica - angelim. Belém: Embrapa Amazônia Oriental; 2004. $101 \mathrm{p}$.

Gonçalves FG, Pinheiro DT, Paes JB, Carvalho AG, Oliveira GL. Durabilidade natural de espécies florestais madeireiras ao ataque de cupim de madeira seca. Floresta e Ambiente 2013; 20(1): 110-116. http://dx.doi.org/10.4322/ floram.2012.063.

Lima JT, Costa-Leonardo AM. Recursos alimentares explorados pelos cupins (Insecta:Isoptera). Biota Neotropica 2007; 7(2): 243-250. http://dx.doi.org/10.1590/S167606032007000200027 .

Loureiro AA, Freitas JA, Freitas CAA. Essências madeireiras da Amazônia. 3. ed. Manaus: MCT/INPA-CPPF; 1997. 116 p.

Loureiro AA, Freitas JA, Ramos KBL, Freitas CAA. Essências madeireiras da Amazônia. 4. ed. Manaus: MCT/ INPA-CPPF; 2000. 191 p.

Marcondes E, Ribeiro MA, Stangerlin DM, Souza AP, Gatto DA. Resistência natural da madeira de duas espécies amazônicas em ensaios de deterioração de campo. Scientia Plena 2013; 9(6): 1-9.

Paes JB. Resistência natural da madeira de Corymbia maculata (Hook.) K. D. HILL \& L.A.S. Johnson a fungos e cupins xilófagos, em condições de Laboratório. Revista Árvore 2002; 26(6): 761-767. http://dx.doi.org/10.1590/ S0100-67622002000600012.

Paes JB, Fonsêca CMB, Lima CR, Souza AD. Eficiência do óleo de candeia na melhoria da resistência da madeira de sumaúma a cupins. Cerne 2010; 16(2): 217-225. http:// dx.doi.org/10.1590/S0104-77602010000200014.

Paes JB, Guerra SCS, Silva LF, Oliveira JGL, Teago GBS. Efeito do teor de extrativos na resistência natural de cinco madeiras ao ataque de cupins xilófagos. Ciência Florestal 2016; 26(4): 1259-1269. http://dx.doi.org/10.5902/1980509825137.

Paes JB, Medeiros PN No, Lima CR, Freitas MF, Diniz CEF. Efeitos dos extrativos e cinzas na resistência natural de quatro madeiras a cupins xilófagos. Cerne 2013; 19(3): 399405. http://dx.doi.org/10.1590/S0104-77602013000300006.

Paes JB, Melo RR, Lima CR, Oliveira E. Resistência natural de sete madeiras ao cupim subterrâneo (Nasutitermes corniger Motsch.) em ensaio de preferência alimentar. Agrária 2007b; 2(1): 57-62. http://dx.doi.org/10.5039/ agraria.v2ila1885.

Paes JB, Melo RR, Lima CR. Resistência natural de sete madeiras a fungos e cupins xilófagos em condições de laboratório. Cerne 2007a; 13(2): 160-169.

Paes JB, Vital BR. Resistência natural da madeira de cinco espécies de eucalipto a cupins subterrâneos em testes de laboratório. Revista Árvore 2000; 24(1): 1-6.

Pará. Secretaria de Estado de Meio Ambiente e Sustentabilidade - SEMAS. Relatório de extração e comércio de toras de madeira nativa por essência. Belém; 2017. 
Paula JE, Alves JLH. Madeiras nativas: anatomia, dendrologia, dendrometria, produção e uso. 7. ed. Brasília: Fundação Mokiti Okada; 1997. 544 p.

Pereira AF. Madeireiras brasileiras: guia de combinação e substituição. São Paulo: Blucher; 2013. 132 p.

Pereira PAC, Stangerlin DM, Andrade VR No, Rodrigues DA, Melo RR, Corassa JN et al. Efficiency of used oil engine as preservative of Amazonian woods submitted to xylophagous termites. Revista Ciência da Madeira 2015; 6(3): 176-182. http://dx.doi.org/10.12953/2177-6830/ rcm.v6n3p176-182.

Rodrigues RB, Brito EO. Resistência natural de Eucalyptus urophylla e Corymbia citriodora à Coptotermes gestroi (Isoptera; Rhinotermitidae) em Laboratório. Floresta e Ambiente 2011; 1(18): 9-15. http://dx.doi.org/10.4322/ floram.2011.018.

Santos E. Nossas madeiras. Belo Horizonte: Itatiaia; 1987. 316 p.

Silva JC, Caballeira Lopez AG, Oliveira JTS. Influência da idade na resistência natural da madeira de Eucalyptus grandis
W. HILL ex. Maiden ao ataque de cupim de madeira seca (Cryptotermes brevis). Revista Árvore 2004; 28(4): 583-587. http://dx.doi.org/10.1590/S0100-67622004000400012.

Stallbaun PH, Barauna EEP, Paes JB, Ribeiro NC, Monteiro TC, Arantes MDC. Resistência natural da madeira de Sclerolobium paniculatum Vogel a cupins em condições de laboratório. Floresta e Ambiente 2017; 24: e20160013.

Stangerlin DM, Costa AF, Garlet A, Pastore TCM. Resistência natural da madeira de três espécies amazônicas submetidas ao ataque de fungos apodrecedores. Ciência da Madeira 2013; 4(1): 15-32. http://dx.doi.org/10.12953/2177-6830. v04n01a02.

Supriana N. Notes the resistance of tropical wood against termites. Stockholm: The International Research Group on Wood Preservation; 1985. 9 p. Doc. IRG/WP/1249.

Vasconcellos FJ, Freitas JÁ, Lima VMOC, Monteiro LV, Pereira SJ. Madeiras tropicais de uso industrial do Maranhão: características tecnológicas. Manaus: INPA/ UFMA; 2001.96 p. 